\title{
Perinatal Protein Undernutrition and Cardiovascular System: A Systematic Review
}

\author{
José Emerson Xavier ${ }^{1}$ Erivaldo Alves Antonio ${ }^{1}$ Lisiane dos Santos Oliveira ${ }^{2}$ Sandra Lopes de Souza ${ }^{3}$ \\ Juliana Pinto de Medeiros ${ }^{1}$ Lavínia Calmon Lima ${ }^{4}$ Carlos Alberto de Carvalho Fraga ${ }^{4}$ \\ Rafael Danyllo da Silva Miguel ${ }^{4}$
}

${ }^{1}$ Department of Histology and Embryology, Centro de Biociências, Universidade Federal de Pernambuco, Recife, PE, Brazil

2 Department of Nursery, Centro Acadêmico de Vitória, Universidade Federal de Pernambuco, Vitória de Santo Antão, PE, Brazil

3 Departament of Anatomy, Centro de Biociências, Universidade Federal de Pernambuco, Recife, PE, Brasil

${ }^{4}$ Department of Medicine, Universidade Federal de Alagoas, Arapiraca, AL, Brazil

\author{
Address for correspondence José Emerson Xavier, Master, \\ Departamento de Histologia e Embriologia, Centro de Biociências, \\ Universidade Federal de Pernambuco - UFPE, Avenida da Engenharia, \\ SN, Cidade Universitária, CEP 50740-600, Recife, PE, Brasil \\ (e-mail: joseemersonxavier@gmail.com).
}

J Morphol Sci 2018;35:203-206.

\begin{abstract}
The present study is a systematic review of the literature that aimed to characterize the profile in animal models used to study perinatal protein malnutrition correlating with the cardiovascular system and the implications of malnutrition to the heart. Therefore, an extensive search was conducted in the PubMed, BVS, and SciELO databases, using combinations of the descriptors protein malnutrition, pregnancy, heart, lactation, and cardiovascular system. A total of 247 articles were found, but after excluding duplicities and applying the inclusion/exclusion criteria, only 12 papers remained. The analysis of

Keywords

- cardiovascular diseases

- heart

- offspring

- undernutrition the results shows that the diet used in the studies has a protein content of between 17 and $22 \%$ for the control animals, and of between 0 and $9 \%$ for the animals submitted to perinatal protein malnutrition. The main morphofunctional changes observed in the cardiovascular system are related to high blood pressure, increased apoptosis of cardiomyocytes, and reduction in the absolute size of the heart, among other ultrastructural and molecular changes.
\end{abstract}

\section{Introduction}

During the period of gestation and lactation, the developing organism is more vulnerable to external stimuli, being able to adapt to those stimuli to survive. Although these adaptations are evolutionarily beneficial to the organism, they are the main factor for the emergence of diseases in adult life as well, if the environment in adult life is different from the perinatal environment. ${ }^{1}$

The cardiovascular system is the first system to develop during the embryonic period. However, the cardiomyocytes continue to proliferate for a while in the postnatal period. ${ }^{2}$ Several elements are important to maintain the integrity of this system, such as zinc, which is necessary for the cardiac development, ${ }^{3}$ and tryptophan, which is important for the development of the cardiorespiratory center in the medulla oblongata. ${ }^{4}$ Thus, a balanced diet is essential for pregnant women to promote a healthy development of the fetus.

In experimental models with the number of offspring of Wistar rats adjusted to 3 pups per female, there was an induction of obesity in the offspring, promoting several consequences in the cardiovascular system. Among those alterations, it is possible to identify an increase in the myocardial sympathetic tone, ${ }^{5}$ left ventricular hypertrophy, ${ }^{6}$ cardiac hypertrophy, and an increased risk of developing ischemia. ${ }^{7}$ At the molecular levels, hypernutrition during the lactation period is still capable of promoting damage to the insulin received

August 29, 2018

accepted

September 6, 2018

published online

October 31, 2018
DOI https://doi.org/

10.1055/s-0038-1675361. ISSN 2177-0298.
Copyright $(2018$ by Thieme Revinter

Publicações Ltda, Rio de Janeiro, Brazil
License terms

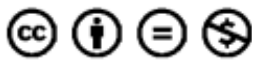


signaling pathway, as well as an increased expression of glucose transporter 1 (GLUT-1), ${ }^{8}$ an increased expression of insulin and leptin receptors in the myocardium, and translocation of glucose transporter 4 (GLUT-4) to the plasma membrane. ${ }^{9}$

On the other hand, protein malnutrition during the perinatal period is also capable of promoting morphological and functional damage to the cardiovascular system. ${ }^{10-12}$ Experimental models that restrict the amount of casein in the food of rats and mice are quite widespread in the scientific literature. However, the protein content used in the diet of pregnant female rats and the gender of their offspring vary considerably. Starting from this point, the objectives of the present study were to characterize the animal models used in studies that relate perinatal protein malnutrition and the cardiovascular system, identifying the gender of the animals and the casein content of their diets; and to analyze the morphofunctional implications caused by perinatal protein malnutrition on the heart of rats.

\section{Materials and Methods}

The present study is a systematic review of the literature performed individually by two researchers in a double-blind procedure between June 22 and 25 2017. The literature search was performed in the PubMed, BVS, and SciELO databases, using combinations of the descriptors protein malnutrition, pregnancy, heart, lactation, and cardiovascular system, all present in the list of Health Sciences Descriptors (DeCS, in the Portuguese acronym).
All of the articles were placed in a Microsoft Excel (Microsoft Corp, Redmond, WA, USA) spreadsheet. ${ }^{13}$ Afterwards, the titles and summaries of each article were analyzed. Therefore, to characterize the model of animal submitted to perinatal protein malnutrition associated with changes in the cardiovascular system, the following inclusion criteria were used: a) original articles that used exclusively perinatal protein malnutrition in rats; and b) articles that approached morphofunctional alterations of the cardiovascular system. The use of the first criteria allowed characterizing the animal model used in the studies that correlated perinatal protein malnutrition with the cardiovascular system, corresponding to the first objective of the present study. On the other hand, the second criteria enabled the analysis of the morphofunctional changes in the heart, specifically in rats, which corresponds to the second objective of the present study.

\section{Results}

In total, 247 articles were found in the 3 analyzed databases. The numbers of articles found in each database, according to the respective combination of the descriptors, are shown in - Table 1. However, after excluding duplicities and applying the inclusion/exclusion criteria, just 12 articles remained.

The protein content of the diets of the animals in the control groups varied between 17 and $22 \%$, while the protein content of the diets of the malnourished animals ranged from 0 to $9 \%$. Among all the articles found, 8 used only male rats (66\%), 1 (8.5\%) used both genders, 1 (8.5\%) used only

Table 1 Number of articles found in each database according to the combination of the descriptors

\begin{tabular}{|l|l|l|l|}
\hline COMBINATION OF DESCRIPTRS & PUBMED & BVS & SCIELO \\
\hline protein malnutrition AND pregnancy AND heart & 62 & 62 & 1 \\
\hline protein malnutrition AND lactation AND heart & 17 & 19 & 1 \\
\hline protein malnutrition AND lactation AND cardiovascular System & 14 & 8 & 0 \\
\hline protein malnutrition AND pregnancy AND cardiovascular System & 46 & 17 & 0 \\
\hline
\end{tabular}

Table 2 Summary of the main results found in the selected articles related to perinatal protein malnutrition and the cardiovascular system of offspring of rats

\begin{tabular}{|l|l|l|l|}
\hline AUHTORS & DIET & SEX & MAIN RESULTS \\
\hline Tappia et al. $^{16}$ & NP: 18\%; LP 9\% & Male & $\begin{array}{l}\text { Perinatal protein malnutrition stimulated an increase in the ventricular } \\
\text { wall in rats from the fourth week of life. Furthermore, the internal } \\
\text { diameter of the left ventricle is greater in malnourished animals as well. } \\
\text { These findings were associated with increased gene expression that } \\
\text { decodes proteins involved in glucose transport and metabolism. }\end{array}$ \\
\hline Gama et al. $^{14}$ & NP: 18.7\%; LP: 5\% & Untold & $\begin{array}{l}\text { In the 21st day of life, the hearts of animals submitted to perinatal } \\
\text { malnutrition were smaller than the control animals. Moreover, it was } \\
\text { observed the presence of polymorphic cardiomyocytes, numerous } \\
\text { vacuoles, irregular microfilaments, polymorphic mitochondria with dis- } \\
\text { organized cristae, and it has been verified that even the heart size being } \\
\text { reduced by about 50\%, the number of granules of atrial natriuretic } \\
\text { peptide did not reduce. }\end{array}$ \\
\hline Brawley et al. ${ }^{21}$ & NP: 18\%; LP: 9\% & Male & $\begin{array}{l}\text { The animals submitted to perinatal protein malnutrition showed an } \\
\text { increase in blood pressure during the 130th day of life and reduced } \\
\text { vasodilatory activity (Between the 87th and 164th day of life) when } \\
\text { compared to the control group. }\end{array}$ \\
\hline
\end{tabular}


Table 2 (Continued)

\begin{tabular}{|c|c|c|c|}
\hline AUHTORS & DIET & SEX & MAIN RESULTS \\
\hline Holness et al. ${ }^{13}$ & NP: $20 \% ;$ LP: $8 \%$ & Untold & $\begin{array}{l}\text { Animals subjected to perinatal protein malnutrition and remained with } \\
\text { poor protein diet in adulthood did not present significant differences in } \\
\text { glucose utilization compared to the control group. On the other hand, } \\
\text { rats that were submitted to perinatal protein malnutrition and then } \\
\text { receive a normoproteic diet exhibited reduced glucose utilization. }\end{array}$ \\
\hline Akamatsu et al. ${ }^{20}$ & NP: 20\%; LP: 5\% & Male & $\begin{array}{l}\text { Animals that have been subjected to protein malnutrition during preg- } \\
\text { nancy and up to the } 21 \text { st day postnatal life and then receive a normo- } \\
\text { proteic diet for another } 21 \text { days showed an increase in ribosome density } \\
\text { on the endoplasmic reticulum in comparison with animals that remained } \\
\text { on a hypoproteic diet. However, the number of ribosomes in the } \\
\text { endoplasmic reticulum was lower in animals that always received a } \\
\text { normoproteic diet. In addition, the animals that changed the diet of hypo } \\
\text { to normoproteic on the } 21 \text { st day of life showed intermediate density of } \\
\text { chromatin and mitochondria with oblique cristae, while in the animals } \\
\text { that maintained the malnutrition and in the animals that always received } \\
\text { normal diet these cristae were irregular and transverse, respectively. }\end{array}$ \\
\hline Moura et al. ${ }^{15}$ & NP: 22\%; LP: 0\% & $\begin{array}{l}\text { Both } \\
\text { sexes }\end{array}$ & $\begin{array}{l}\text { Perinatal protein malnutrition promoted the relative increase of the heart } \\
\text { in both sexes (heart/body) on the 8th day of life. Furthermore, in the same } \\
\text { period, the heart of females showed a larger growth when compared to } \\
\text { the heart of males, but in the second month of life there are no significant } \\
\text { differences between these groups. }\end{array}$ \\
\hline Akamatsu et al. ${ }^{18}$ & NP: 20; LP: $5 \%$ & Male & $\begin{array}{l}\text { Perinatal protein malnutrition decreased the number of neurons in the } \\
\text { subepicardial ganglia of male rats. }\end{array}$ \\
\hline Barros et al. ${ }^{5}$ & NP: $17 \%$; LP: $8 \%$ & Male & $\begin{array}{l}\text { Perinatal protein malnutrition elevates the level of sympathetic tone in } \\
\text { the heart of Wistar rats and contributes to the increase in blood pressure. }\end{array}$ \\
\hline Cheema et al. ${ }^{17}$ & NP: 18\%; LP: 9\% & Male & $\begin{array}{l}\text { The fraction of blood ejection is lower in the animals that were submitted } \\
\text { to perinatal protein malnutrition when compared to the control group. In } \\
\text { addition, it was verified that this reduction in blood ejection is a result of } \\
\text { cardiomyocyte loss due to increased apoptosis. }\end{array}$ \\
\hline $\begin{array}{l}\text { Augustyniak et } \\
\text { al. }{ }^{23}\end{array}$ & NP: 18\%; LP: 6\% & Male & $\begin{array}{l}\text { Animals submitted to perinatal protein malnutrition showed an increase } \\
\text { in blood pressure when compared to control group after feeding for five } \\
\text { weeks on a high-salt diet }(4 \%) \text {. }\end{array}$ \\
\hline Torrens et al. ${ }^{22}$ & NP: 18\%; LP: 9\% & Female & $\begin{array}{l}\text { Female rats that were submitted to perinatal protein malnutrition } \\
\text { presented vasodilator dysfunction in the arteries during gestation. }\end{array}$ \\
\hline Akamatsu et al. ${ }^{19}$ & NP: 20; LP: 5\% & Male & $\begin{array}{l}\text { The rough endoplasmic reticulum of animals submitted to perinatal } \\
\text { protein malnutrition exhibited a lower density of ribosomes. Moreover, } \\
\text { the chromatin density in malnourished animals was lower than in the } \\
\text { control group as well. The mitochondrial cristae folds were irregular, while } \\
\text { in the control group these cristae were transversal. }\end{array}$ \\
\hline
\end{tabular}

Abbreviations: NP, Normal Protein; LP, Low Protein.

female rats, and the remaining 2 (17\%) did not report the gender of the animals. The summary of the main results obtained are described in - Table 2 . $^{5,13-23}$

\section{Conclusions}

Through the analysis of the results observed in all articles, it was possible to identify that the casein content used in most studies was $18 \%$ for the control group and $9 \%$ for the undernourished group. In general, although perinatal protein malnutrition promotes a reduction in the body weight of animals and an absolute reduction of the size of the heart, ${ }^{14}$ the relative size of the heart (heart weight/body weight) is higher in animals submitted to protein deficiency in the perinatal period, in both genders. ${ }^{15}$ The comparison between the absolute thicknesses of the left ventricle of animals whose mothers received a normoproteic and a hypoproteic diet indicates that malnutrition reduces the ventricular thickness in the animals during the period between the first 24 hours of life until the $8^{\text {th }}$ week, when there is a significant increase in the thickness of the ventricular wall in malnourished offspring. ${ }^{16}$ The observed hypertrophy of the ventricle was correlated with the increased expression of proteins related to the glucose metabolism, which suggests that the cardiac remodeling observed in those animals may be due to an increase in the myocardial glucose uptake. ${ }^{16}$

On the other hand, the internal diameter of the left ventricle in malnourished animals was wider since the first 24 hours of postnatal life, remaining in this state up to the $8^{\text {th }}$ week. ${ }^{16}$ During the first 2 weeks of life, a reduced ejection fraction was observed, occurring in the same period that there was a higher degree of cardiomyocyte apoptosis. ${ }^{17}$ 
In addition to the ventricular changes, alterations in the atria were also verified. The atrial wall is responsible for the release of atrial natriuretic peptide. This hormone is involved in the control of the balance of electrolytes and body fluids, which is involved in the development of hypertension. ${ }^{24-26}$ The atrial cardiomyocytes of animals submitted to protein malnutrition during pregnancy did not present a reduction in the number of granules of atrial natriuretic peptide, even when the heart size was reduced by $\sim 50 \% .{ }^{14}$ In the ultrastructural analysis of these cells, it can be verified that perinatal protein malnutrition promotes the appearance of numerous cytoplasmic vacuoles, associated with irregular microfilaments, polymorphism at the cardiomyocytes, and polymorphic mitochondria containing disorganized mitochondrial cristae. ${ }^{14}$

The morphological changes in the heart of malnourished rats were not restricted to the cardiomyocytes. It was observed that perinatal protein malnutrition further damages the development of subepicardial neurons. ${ }^{18-20}$ In these neurons, a reduction in the number of ribosomes in the rough endoplasmic reticulum was verified, reducing the distribution of chromatin and altering the morphology of the mitochondrial cristae, from transverse to irregular.

All of the morphological alterations in the heart associated with increased sympathetic tone ${ }^{5}$ and with vascular changes $^{21,22}$ also lead to an increase in blood pressure in the animals submitted to perinatal protein malnutrition. Furthermore, the offspring subjected to perinatal malnutrition are more vulnerable to increased blood pressure after the intake of a high-sodium diet for a given period. ${ }^{23}$

The results show that most of the protein malnutrition models used to verify morphological changes in the cardiovascular system use a normoproteic diet with a protein content of $18 \%$ and a hypoproteic diet of 5 or $9 \%$. Furthermore, it was possible to verify that perinatal protein malnutrition provokes an increase in blood pressure due to both morphological and ultrastructural alterations of the cardiomyocytes and of the subendocardial neurons.

\section{References}

1 Barker DJ. The developmental origins of adult disease. Eur J Epidemiol 2003;18(08):733-736

2 Li F, Wang X, Capasso JM, Gerdes AM. Rapid transition of cardiac myocytes from hyperplasia to hypertrophy during postnatal development. J Mol Cell Cardiol 1996;28(08):1737-1746

3 Tomat AL, Juriol LV, Gobetto MN, et al. Morphological and functional effects on cardiac tissue induced by moderate zinc deficiency during prenatal and postnatal life in male and female rats. Am J Physiol Heart Circ Physiol 2013;305(11):H1574-H1583

4 Penatti EM, Barina AE, Raju S, et al. Maternal dietary tryptophan deficiency alters cardiorespiratory control in rat pups. J Appl Physiol (1985) 2011;110(02):318-328

5 Barros MA, De Brito Alves JL, Nogueira VO, Wanderley AG, CostaSilva JH. Maternal low-protein diet induces changes in the cardiovascular autonomic modulation in male rat offspring. Nutr Metab Cardiovasc Dis 2015;25(01):123-130

6 Moreira AS, Teixeira Teixeira M, da Silveira Osso F, et al. Left ventricular hypertrophy induced by overnutrition early in life. Nutr Metab Cardiovasc Dis 2009;19(11):805-810
7 Vieira AK, Soares VM, Bernardo AF, et al. Overnourishment during lactation induces metabolic and haemodynamic heart impairment during adulthood. Nutr Metab Cardiovasc Dis 2015;25(11): 1062-1069

8 Bernardo AF, Cortez E, Neves FA, et al. Overnutrition during lactation leads to impairment in insulin signaling, up-regulation of GLUT1 and increased mitochondrial carbohydrate oxidation in heart of weaned mice. J Nutr Biochem 2016;29:124-132

9 Pereira RO, Moreira AS, de Carvalho L, Moura AS. Overfeeding during lactation modulates insulin and leptin signaling cascade in rats' hearts. Regul Pept 2006;136(1-3)117-121

10 Moussa YY, Tawfik SH, Haiba MM, et al. Disturbed nitric oxide and homocysteine production are involved in the increased risk of cardiovascular diseases in the F1 offspring of maternal obesity and malnutrition. J Endocrinol Invest 2017;40(06):611-620

11 Braz GRF, Emiliano AS, Sousa SM, et al. Maternal low-protein diet in female rat heart: possible protective effect of estradiol. J Dev Orig Health Dis 2017;8(03):322-330

12 de Brito Alves JL, de Oliveira JM, Ferreira DJ, et al. Maternal protein restriction induced-hypertension is associated to oxidative disruption at transcriptional and functional levels in the medulla oblongata. Clin Exp Pharmacol Physiol 2016;43(12):1177-1184

13 Holness MJ, Priestman DA, Sugden MC. Impact of protein restriction on the regulation of cardiac carnitine palmitoyltransferase by malonyl-CoA. J Mol Cell Cardiol 1998;30(07):1381-1390

14 Gama EF, Liberti EA, de Souza RR. Effects of pre-and postnatal protein deprivation on atrial natriuretic peptide-(ANP-) granules of the right auricular cardiocytes. Eur J Nutr 2007;46(05):245-250

15 Sanchez Moura A, Gomes Pereira F, Mandarim-de-Lacerda CA. Gender determines long-lasting effects on adult offspring heart after early-life malnourishment. Biol Neonate 2004;85(04):256-262

16 Tappia PS, Guzman C, Dunn L, Aroutiounova N. Adverse cardiac remodeling due to maternal low protein diet is associated with alterations in expression of genes regulating glucose metabolism. Nutr Metab Cardiovasc Dis 2013;23(02):130-135

17 Cheema KK, Dent MR, Saini HK, Aroutiounova N, Tappia PS. Prenatal exposure to maternal undernutrition induces adult cardiac dysfunction. Br J Nutr 2005;93(04):471-477

18 Akamatsu FE, et al. Low protein diet during perinatal period decreases the number of subepicardial neurons in rats. Braz J Morphol Sci 2009;26(3-4)181-185

19 Akamatsu FE, et al. Effect of prenatal low-protein diet in subepicardial neuron of rat: a morphological study. J Morphol Sci 2010;27(02):82-87

20 Akamatsu FE, et al. Effects of protein deprivation and refeeding on the subepicardial neurons of rat: subepicardial neurons and lowprotein diet. J Morphol Sci 2011;28(02):120-128

21 Brawley L, Itoh S, Torrens C, et al. Dietary protein restriction in pregnancy induces hypertension and vascular defects in rat male offspring. Pediatr Res 2003;54(01):83-90

22 Torrens C, Kelsall CJ, Hopkins LA, Anthony FW, Curzen NP, Hanson MA. Atorvastatin restores endothelial function in offspring of protein-restricted rats in a cholesterol-independent manner. Hypertension 2009;53(04):661-667

23 Augustyniak RA, Singh K, Zeldes D, Singh M, Rossi NF. Maternal protein restriction leads to hyperresponsiveness to stress and salt-sensitive hypertension in male offspring. Am J Physiol Regul Integr Comp Physiol 2010;298(05):R1375-R1382

24 Toyoshima Y, Suzuki S, Awal MA, et al. Atrial natriuretic peptide (ANP)-granules of auricular cardiocytes in dehydrated and rehydrated mice. Exp Anim 1996;45(02):135-140

25 de Bold AJ, Borenstein HB, Veress AT, Sonnenberg H. A rapid and potent natriuretic response to intravenous injection of atrial myocardial extract in rats. Life Sci 1981;28(01):89-94

26 Yoshihara F, Nishikimi T, Kosakai Y, et al. Atrial natriuretic peptide secretion and body fluid balance after bilateral atrial appendectomy by the maze procedure. J Thorac Cardiovasc Surg 1998;116 (02):213-219 